\title{
Assessment of the Effects of Flood on Agricultural Land Use in Doma Local Government Area, Nasarawa State, Nigeria
}

\author{
Anzaku M. Iliyasu ${ }^{1} \quad$ Alkali Mohammed ${ }^{2} \quad$ Buba Y. Alfred $^{4} \quad$ L.M. Akpami ${ }^{3} \quad$ Sa'adu Sabitu Da' $^{1}$ \\ 1.School of Continuing Education, Department of Sciences, Bayero University, Kano, Nigeria \\ 2.Department of Environmental Sciences, Nasarawa State University Keffi, Nasarawa State, Nigeria \\ 3.Department of Geography, Nasarawa State University Keffi, Nasarawa State, Nigeria \\ 4.Nigerian Building \& Road Research Institute, 10 NBRRI Road/ I.T. Igbani Street, Jabi District, Abuja, FCT, \\ Nigeria
}

\begin{abstract}
This study aimed at assessing the effects of flood on agricultural land use in Doma Local Government Area, Nasarawa state, Nigeria. In order to achieve the objectives of the study, information on the causes effects frequency and magnitude of flood on agricultural land use were needed from primary and secondary source of data. The primary data were obtained through the use of structured questionnaire, field observation and measurement and ten years rainfall data (2004-2014). The rainfall data were obtained from Nigeria meteorological agency (NIMET), Lafia, Nasarawa state. Rainfall data obtained were used for rainfall trend analysis for the study. The secondary data include information from relevant text such as journals, newspaper dictionary, encyclopaedia textbooks, internet and web and related past students dissertation and thesis. Basic statistical techniques such as the computation of totals, mean, and standard deviation were employed for the analysis of rainfall data. Descriptive statistics were adopted to analyze the result from the questionnaire and simply linear regression analysis were used to determined rainfall trend for this work. The study shows that there has an appreciable effect of flood in the study area which is due to many factors such as human activities but is greatly influenced by climate. This evident in the study as about $44.1 \%$ and $21.8 \%$ of the total respondents have been engaged in farming for 21 years and above, and 16 to 20 years respectively and are thereby able to explain clearly the effects they home observed experienced over time. The finding also revealed that $1.76 \%$ of the respondents have lost a total 15 hectares of farm land, $30.59 \%$ have 416 hectare 23.53 have lost 480 hectares, $14.71 \%$ lost 500 histories and $7.06 \% 600$ hectares respective. This indicates a great destruction farm lands in the area and invariably a decrease in food production. The state disaster management and other agencies charges with disaster management in the state level should be properly funded in order to respond to the challenges of sudden of occurrences of natural disaster in future.
\end{abstract}

Keywords: Effect, Floods, Agriculture, Landuse, Devastation

DOI: $10.7176 / \mathrm{JEES} / 9-3-08$

Publication date:March $31^{\text {st }} 2019$

\subsection{INTRODUCTION}

Man has from pre-historical times, been engaged in a never-ending battle with natural hazards or extreme events in his bid to utilize the resources of the earth. Those hazards by definition are functions of both the geological world and human society (Davidson and Dawson, 1979).

Floods remain one of the major causes of natural disasters affecting society. In a study of major natural hazards (excluding droughts) on a world-wide scale over the period 1947 to 1962, Schecham and Hewith (1969) ranked floods first out of sixteen natural disaster types responsible for either 81 million damage or at least 100 persons killed or injured. Altogether floods accounted for about 30 percent of all natural disasters and 40 percent of the fatalities (Schecham and Hawith 1969). In addition, data from the sad statistics of past disasters in the world show that floods and drought for 54 percent of the significant damages, 65 percent of the persons affected and 29 percent of death (DHA, 1994). However, like many other hazards, floods, may also bring benefits, such as the recharge of group water (Smith and Tobin, 1979) and deposition of silly materials quite useful for agricultural purposes.

Since man is unable to control the basic atmospheric processes which produce most floods, he has attempted to adjust to the hazard by means of flood alleviation projects concerned with land-based phase of the hydrological cycle. Through the application of high technological and the massive investment of capital, the flood threat to human life has decreased appreciably in most developed countries within recent decades (Smith and Tobin, 1979). For example, Geroghty et al (1973) estimated that annual deaths resulting from flooding in the USA average more 185 during the period 1931 to 1940 whereas Ward (1978) has indicated that fatalities were reduced to less than 83 per year between 1925 and 1971. It appears that the advanced countries are actually becoming more vulnerable to the loss of property and the social disruption associated with floods. The flood situation developing countries like Nigeria is problematic because of the level of poverty and lack of technological know-how on flood management.

Despite considerable investment in schemes designed to reduce the flood problem mean annual losses have 
continued to rise (Temi E.O, 2006). The year 2012 will remain forever in the minds of many Nigerians as the year when many lives were lost to the agony of flooding. Lagos state for instance, being about five meter below sea level, is prone to floods, thus, when it rained on three consecutive days sometimes the state experienced serious flooding, with residents still counting their losses (Okojie et al 2012) virtually all parts of the state from Victoria Island to Leki, AbuleEgba, Ikeji, Apapa, Oshodi, Ikorodu, Agege, Okokomaiko and Ketu were flooded, forcing residents to stay indoors while those on the street battle to sail through the floods.

In Katsina State also, the people had to contend with the worst flood disaster in the State. According to records, about four Local Government Areas were affected by floods that claimed over six lives; three in Safana, two in Mai'aduand one in Kurfi Local Government Areas of the State. This is even as hundreds of families have been rendered homeless, as the torrential down pour washed away over 1,000 houses, with scores of domestic annuals loss to the disaster (Ibid).

The people of Plateau Southern senatorial cannot, however, forget in a hurry the devastating flood that wreaked havoc to the people. According to National Emergency Management Agency (NEMA), the flood killed 35 persons, while scores of persons were reported missing (Ibid).

According to Nasarawa broadcasting service (NBS) Lafia, the 2012 has been the year of great devastation by flooding. This flooding causes havoc in Lafia, Awe Nasarawa and Doma Local Government Area, of the State. This has led to loss of lives and property as well as loss of Agricultural land use in the affected area.

\subsection{THE STUDY AREA}

Doma Local Government is located between latitude $8^{0} 23^{\prime} \mathrm{N}-8^{0-35}$ and longitude $6^{0} 21 \mathrm{E}-7^{0} 30^{\mathrm{E}}$. It shares boundary in the North by NasarawaEggon Local Government, in the east by Lafia Local Government, Awe Local Government in South-East, Keana Local Government in the north-west, Nasarawa Local Government in the west and Makurdi and Guma Local Government Area of Benue state in the south respectively.Doma is an undulating plain; the steepest slopes of about $8^{0}-15^{0}$ are found in the south western part dipping northward and in the northern part. The area has gentle slopes (Offodile, 1991).

Doma Local Government is situated on the parents rocks type beneath the earth crust belongs to the two main rock types that are found in the central northern plates and the fringes of River Niger and River Benue respectively, these are the metamorphic and younger sedimentary rocks respectively. The area has a tropical type of climate. The area is characterised by tropical ferruginous soils. Doma LGA is a well-drained town, when it rains, Doma is drained by the two main streams Orumagye, that runs from north east, it takes it source from Akala hill about few 100 metres about 3 kilometres in between Lafia and Alwaza roads nears the present site of AliyuAkwe (Oriya farm) in Doma and where it eroded into deep gully erosion about 200 metre away and opposite Doma L.G Secretariat at DadinKowaDoma, through Agyaragu by pass. The vegetation of Doma is that of the tropical savanna wood land that is characterised by trees and inter sparsedwith tall grasses, the trees are mostly the deciduous types comprises of locus beans trees, share butters trees and under grown shrubs, that is why the area is easily cleared for farming purposes. 


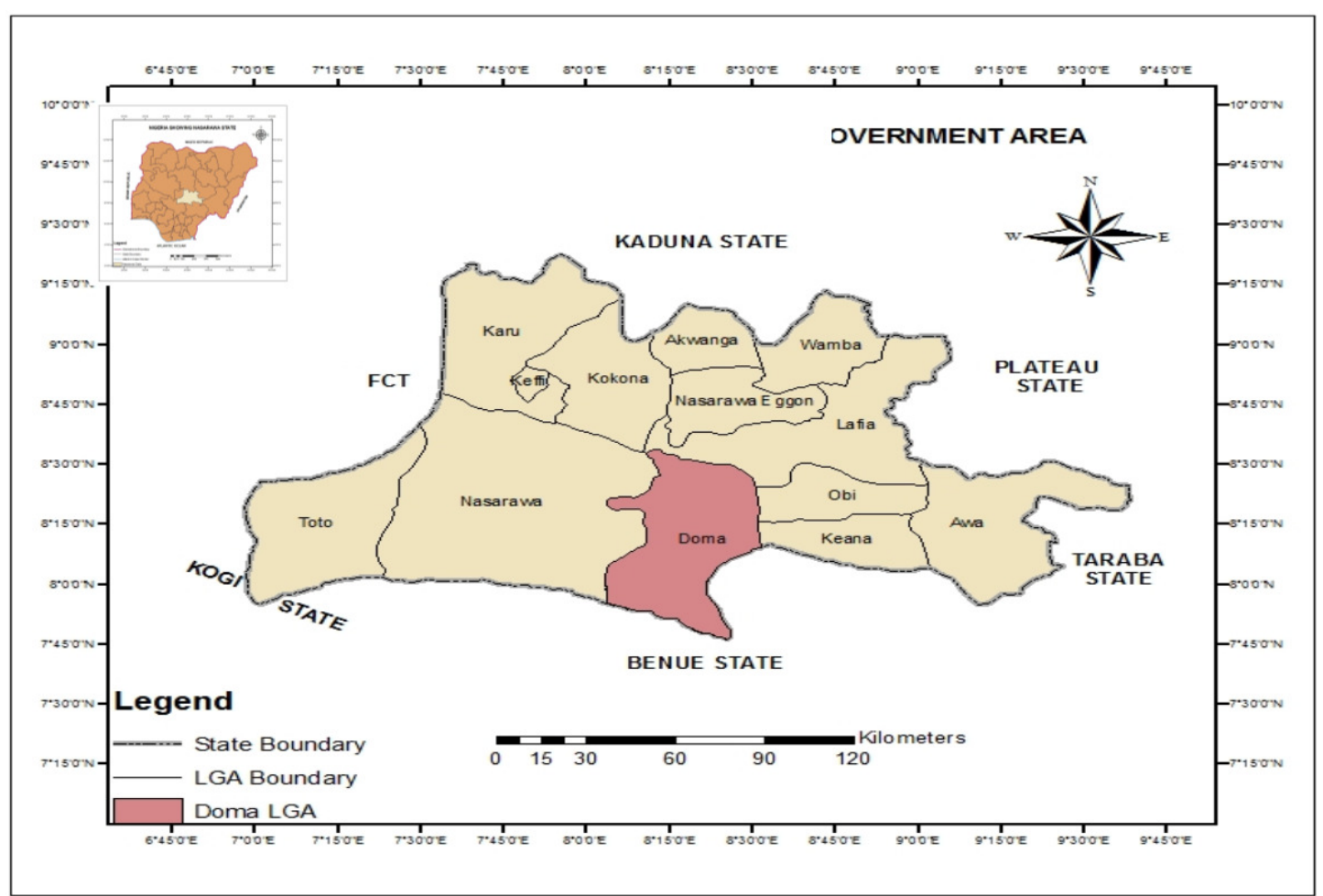

Fig. 1. Map of Nasarawa State showing the study Area.

\subsection{MATERIALS AND METHODS}

Data for this study were sourced from both the primary and secondary souces. The primary data was through the use of structured questionnaire, field observation and field measurement.

The secondary data on the order hand include data on hourly and daily rainfall occurrence which were process for monthly and annual data. The rainfall data were obtained from the Nigeria Meteorological Agency, Lafia, Nasarawa State. This were covered the period 10 years (2004- 2014). Other secondary data were collected from the reports of consultants and other relevant climatological, hydrological, geomorphological and environmental reports, as well as relevant data on land uses map and other relevant maps from Nasarawa State ministry of land and survey, Lafia.

\subsection{Reconnaissance Survey}

A preliminary survey that acquaint the researcher with the general characteristics of the flood prone areas in Doma Local Government Area. The survey particularly aid the researcher to know the different activities taking place in the study area.

\subsection{Field Measurement}

Instrument such as tape and ranging poles were used to measure the length and width of the affected agricultural land use in the study area. The result were determined in metre. Field book was used to record the figure from the field. At the end of the study, extent of area affected by flood on agricultural land use in the study were also determined.

\subsection{Method of Data Collection}

Farmers perception on the causes, effect and the consequences of floods on agricultural land use in Doma Local Government Area were sourced with the used of questionnaire. 200 copies of questionnaires were administered to farmers in the study area. The questionnaire structured into five sections. Section "A" of the questionnaires contained information on socio-economic characteristics of the respondents, section "B" focuses on the causes of floods in the study area, section "C" of the questionnaire contained information the effects of floods on agricultural land use in the study area, section four of the questionnaire has to do with farmer perception on floods in the area while section five of the questionnaire deal with the suggested measures that could be adopted to alleviate the effect of flooding in the area.

\subsection{Statistical Techniques}

Basic statistical techniques such as the computation of totals, means and standard deviation were employed for the 
analysis of rainfall data in the study area. Descriptive statistics were adopted to analyse the result from the questionnaire and finally, simply linear regression analysis were used to determined rainfall trend in the study area.

\subsection{RESULTS AND DISCUSSION}

This section deals with the presentation, analysis and discussion of results obtained. The data are analysed using frequencies, percentages, tables, and charts. The Pearson Moment Correlation was used to test the hypothesis. Personal and farmland data of respondents were interviewed including that of flood; responses and adjustments to flood were also gathered. Rainfall data of the study area were observed.

\subsection{Identification and Mapping of Flood Prone Areas in Doma LGA}

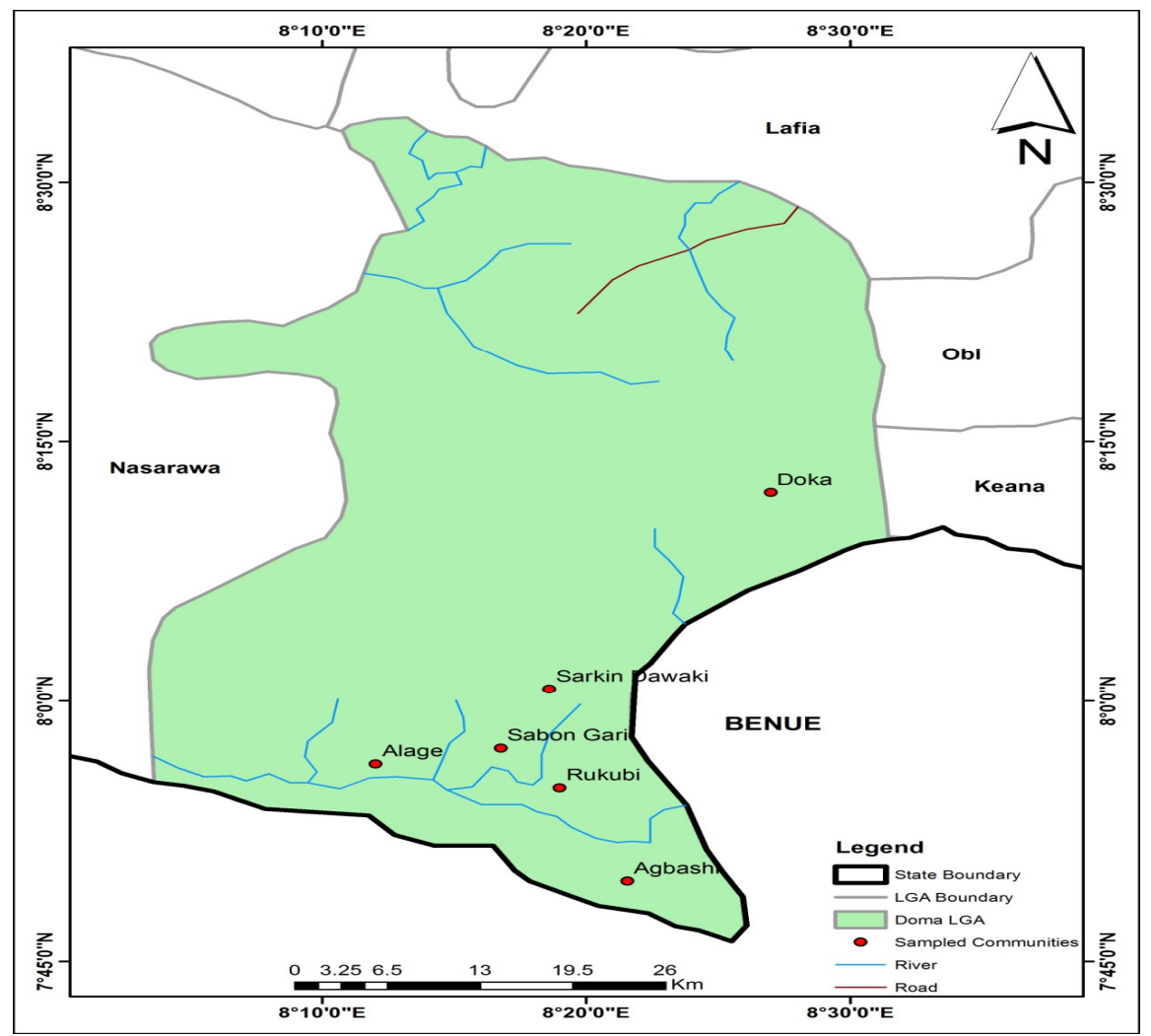

Fig.2: Map of Doma showing areas prone to flood.

Figure 2 present information on area prone to flood in Doma Local Government Area of Nasarawa State. This area includes Agbashi, Rukubi, Sabongari, Alage, SarkinDawaki respectively. These area were prone because of their location to lee ward site in Doma.

\subsection{Crop Yield of the Respondents Farmlands between 2006 to 2015}

Figures 1 and 2 show the variations in crop yield of flood affected farmlands in the study area. It revealed an inverse relationship between the years the respondents were affected by flood and crop yields in bags. Figure 4.1 present the intensity of flood in the various years while figure 4.2 present the frequencies of respondents' crops yield for the period of ten (10) years.

Figure 2 revealed high rate of farm devastation by flood in the years: 2012, 2008, 2011, 2007 and 2009. Within the ten years period used for this study, the peak of period of farmland devastation by flood in the study according to the respondents occurred in 2012. This was due to the nation-wide flood that affected most part of the country in the year following the release of water from the Lagdo dam in Cameroon and the extreme rainfall that also occurred in the year. In 2006, 60 respondents representing $29.41 \%$ indicated that their farms were been affected by flood, 47.06 respondents made the same claim in 2007. In 2008, the number of respondents whose farmlands were affected by flood was $73.53 \%, 2009$ was $47.06 \%, 2010$ was $11.76 \%, 2011$ was $58.82 \%, 2012$ which was the peak affected farmlands of almost all the respondents representing $97.06 \%$, 2013 was $35.29 \%, 2014$ was $23.53 \%$ while in 2015 it was $29.41 \%$.

Figure 4.2 revealed that the years with the highest effect on farmlands as reported by the respondents (figure 4.1) had the least yields of crops (Groundnut, Maize, Rice, Millet and Guinea corn) cultivated in the study area. Year 2012, 2008, 2011, 2007 and 2009 which were reportedly the years in which farmlands were mostly affected 
had high frequency of respondents that got between 1-20 bags of crops which indicates low yield. Contrarily, the years with less report of farmland devastation by flood had high crop yields in the study area.

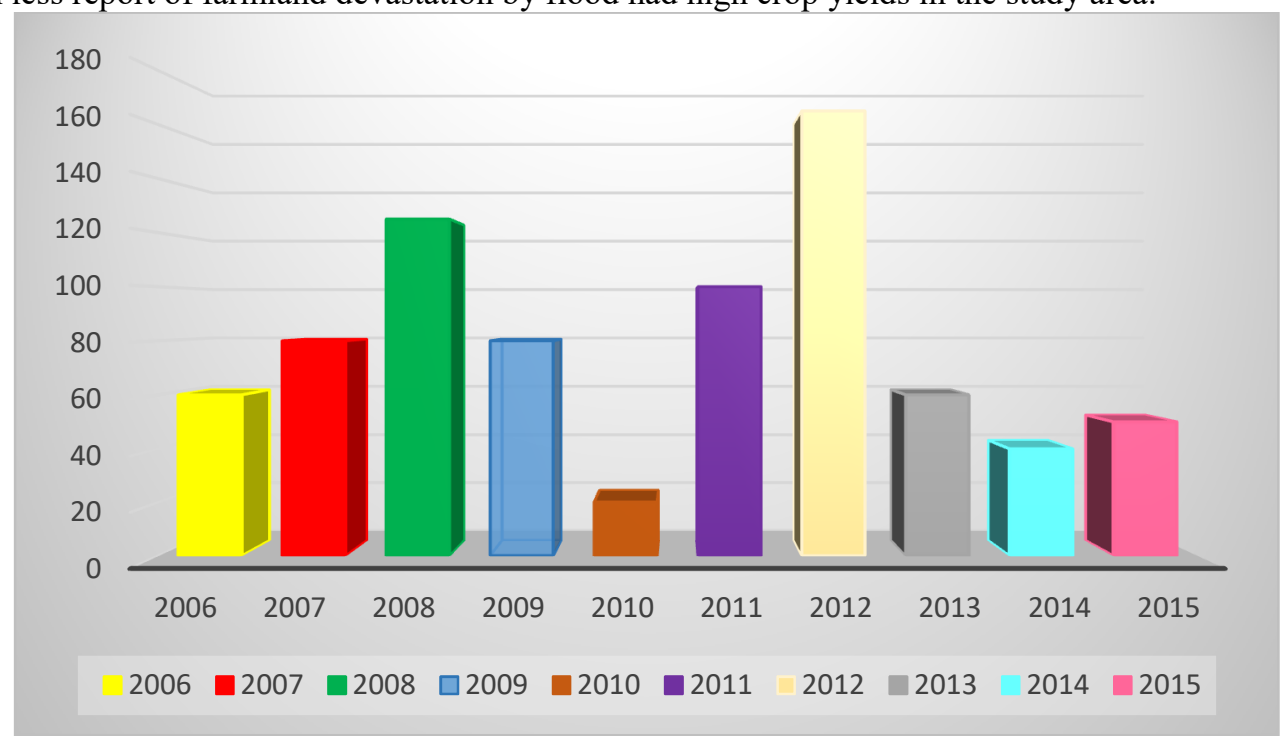

Fig. 3:Years Respondents' Farmlands were affceted by Flood

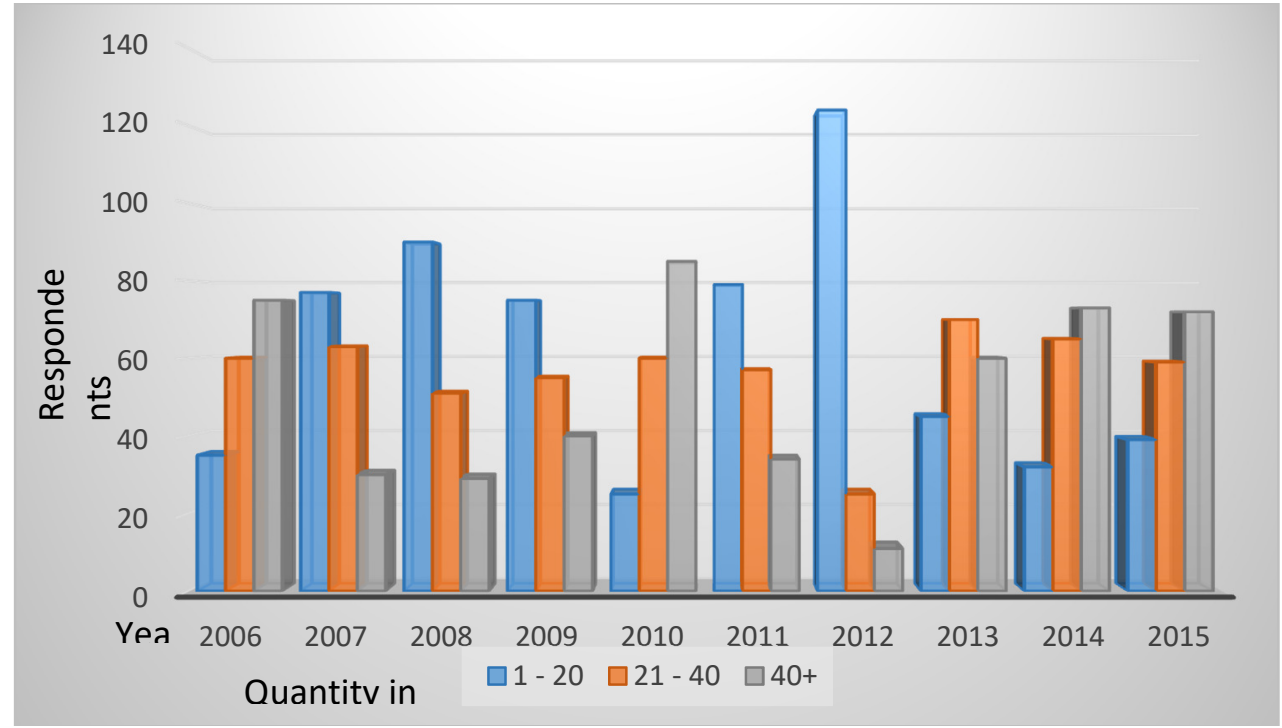

Fig. 4: Crop Production in the Study Area over 10 Years Period 
4.3 Areas of Farmland Affected By Flood and the Value of Crops Damaged in the the Study Area Within The Study Period

Table 1: shows the reponses of the respondents on their farmland areas affcetd by flood, stages of the crops been affeetd in the area covered by flood, quantity of crop yield due to flood and the monetry value of the loss.

\begin{tabular}{|c|c|c|}
\hline Variables & Frequency & Percentage $(\%)$ \\
\hline \multicolumn{3}{|c|}{ Hectares of farmlands ravaged by flood } \\
\hline 5 & 3 & 1.76 \\
\hline 8 & 52 & 30.59 \\
\hline 12 & 40 & 23.53 \\
\hline 20 & 30 & 17.65 \\
\hline 35 & 25 & 14.71 \\
\hline 50 & 12 & 7.06 \\
\hline 80 & 8 & 4.71 \\
\hline Total & 170 & 100 \\
\hline \multicolumn{3}{|c|}{ Stages at which flood affected crops } \\
\hline Matured & 143 & 84.12 \\
\hline Germination & 13 & 7.65 \\
\hline All stages & 14 & 8.24 \\
\hline Total & 170 & 100 \\
\hline \multicolumn{3}{|c|}{ Yield of crops loss in bags } \\
\hline $1-10$ & 25 & 14.71 \\
\hline $11-20$ & 22 & 12.94 \\
\hline $21-30$ & 26 & 15.29 \\
\hline $31-40$ & 20 & 11.76 \\
\hline $41+$ & 77 & 45.29 \\
\hline Total & 170 & 100 \\
\hline \multicolumn{3}{|c|}{ Loss in thousands of naira } \\
\hline $1-20$ & 8 & 4.71 \\
\hline $21-40$ & 16 & 9.41 \\
\hline $41-60$ & 14 & 8.24 \\
\hline $61-80$ & 20 & 11.76 \\
\hline $81+$ & 108 & 61.76 \\
\hline Total & 170 & 100 \\
\hline
\end{tabular}

Source: Field Work (2015)

Table 1 revealed that $1.76 \%$ of the respondents had 5 hectares of their farmlands affected by flood in the study area.30.59\% of the respondents claimed that 8 hectares of their farmlands were destroyed by flood, $23.53 \%$ said they had lost 12 hectares to destructive effect of flood. 20hectares was lost by $17.65 \%$, 35 hectares by $14.71 \%$, 50 by $7.06 \%$ while $4.71 \%$ of the respondents said they lost 80 hectares. Collectively, a total farmland area of 3,626 hectares were lost to flood disaster in the study area in the study area.

When asked at which stage of crops growth does flood affect their farms, about $84 \%$ of the respondents indicated that they are mostly hit when the crops are fully matured. $7.65 \%$ indicated that they are mostly affected at planting/germination stages while the rest $8.24 \%$ said that they are being affected at all stages. Above, most of the respondents said it is difficult for them to replant since the crops are washed away at their matured stage.

In quantifying their crop loss in bags due to flood, $14.71 \%$ of the respondents lost between 1 to 10 bags, $12.94 \%$ lost between 11 and 20, another $15.29 \%$ claimed they lost 21 to 30 bags, $11.76 \%$ lost 31 to 40 bags while $45.29 \%$ constituting most of the respondents lost 41 bags of crops and above to flood. This has affceted their ability to catter for their families needs considering their family sizes (table 4.2) and the triving economic hardship.

Additionaly, majority of the respondents representing $61.76 \%$ value their loss in monetry terms to amount to N81,000 and above, $11.76 \%$ lost betwee N61,000 and N80,000, 8.24\% lost N41,000 to N60,000, 9.47\% lost $\mathrm{N} 21,000$ to N40,000 while $4.71 \%$ lost between the amount of N1000 to N20,000. This indicates that flood in the study area has not only resulted to farmland destruction in the area but has also disrupted the economic activity (farming) through destroying of crops and invariably reduced the living standard of the inhabitants.

\subsection{Adjustment Strategies Adopted by Respondents in the Study Area}

Table 2 shows the various strategies that have been adopted by individuals, governmental and non-governmental agencies toward abating the effects of flood in the study area.

Table 2 Adjustment Strategies Adapted by Respondents

\begin{tabular}{lcc}
\hline Variables & Frequency & Percentage $(\%)$ \\
\hline
\end{tabular}




\begin{tabular}{|c|c|c|}
\hline \multicolumn{3}{|c|}{ Adjustment Strategies Adapted } \\
\hline Bear loss & 81 & 47.65 \\
\hline Seek help & 54 & 31.76 \\
\hline Prayers & 31 & 18.24 \\
\hline Insurance & 1 & 0.59 \\
\hline No response & 3 & 1.75 \\
\hline Total & 170 & 100 \\
\hline \multicolumn{3}{|l|}{ Response to warning } \\
\hline Yes & 56 & 32.94 \\
\hline No & 112 & 65.88 \\
\hline No response & 2 & 1.18 \\
\hline Total & 170 & 100 \\
\hline \multicolumn{3}{|l|}{ Government Awareness } \\
\hline Yes & 154 & 90.59 \\
\hline No & 14 & 8.24 \\
\hline No response & 2 & 1.18 \\
\hline Total & 170 & 100 \\
\hline \multicolumn{3}{|l|}{ Government Response } \\
\hline Provision of relief materials & 128 & 75.29 \\
\hline Sympathy & 17 & 10 \\
\hline \multicolumn{3}{|l|}{ Compensation } \\
\hline No response & $\overline{2} 5$ & $\overline{1} 4.71$ \\
\hline Total & 170 & 100 \\
\hline \multicolumn{3}{|c|}{ Effectiveness of Government Efforts Towards Victims } \\
\hline Adequate & 30 & 17.65 \\
\hline Inadequate & 132 & 77.65 \\
\hline Others & 8 & 4.71 \\
\hline Total & 170 & 100 \\
\hline \multicolumn{3}{|l|}{ NGO's Response } \\
\hline Yes & 34 & 20 \\
\hline No & 131 & 77.06 \\
\hline No response & 5 & 2.94 \\
\hline Total & 170 & 100 \\
\hline \multicolumn{3}{|c|}{ Prevention Measures Adopted } \\
\hline Terracing & 52 & 30.59 \\
\hline Cover crops & 29 & 17.06 \\
\hline Wide channels & 64 & 37.65 \\
\hline Construction of farm dams & 23 & 13.53 \\
\hline No response & 2 & 1.18 \\
\hline Total & 170 & 100 \\
\hline
\end{tabular}

Source: Field Work (2015)

Table 2: revealed that most of the respondents representing $47.65 \%$ only bears their farmland losses due to flood themselves, $31.76 \%$ said they seek help from relatives, friends, families and cultural unions. $18.24 \%$ said they only offer prayers to their God/gods, $0.59 \%$ of responded that whenever flood washed away their farmlands and crops, insurance company comes to their rescue, while $1.75 \%$ had no response to the question.

The respondents also acknowledged early warning as one of the adaptive strategies they implore to cope with flood disaster in the study area. 56 of the respondents representing $32.94 \%$ indicated that they do receive early warning and thus responded by planting early so that before the crops could be harvested before the months during which flood hits the area most. However a lrage number of the respondents representing 65.88\% indicated not receiving the early warning while two (2) respondents made no response the early warning question.

Also on the question regarding government awareness of flood events in the study area, 154 respondents representing $90.59 \%$ affirmed that the government is aware of the menace, $8.24 \%$ answered no while the rest $1.18 \%$ did not comment on the issue.

Regarding the measures being taking by the government to help cob the flood menace in the area, greater percentage of the respondents (75.29) said that the government often provided relief materials to the affected persons. They noted that some of the relief materials provided by the government included: fertilizers, food stuff, clothes and roofing sheets. However, they also noted that these materials often don't get to the right people as the distribution is in most cases politically influenced. $10 \%$ said that the government only sympathizes with the victims, 
there was no response for compensation while the rest 25 respondents could not say anything to the question.

In measuring the effectiveness of the government efforts towards flood control in the area, $17.65 \%$ of the respondents that government measures are adequate, but on the contrary, a lrage number of the respondents representing $77.65 \%$ said that governments efforts towards flood control in the area were inadequate while the rest $4,71 \%$ claimed that there are other measures that the government should have (in addition to what's on ground) provided to control flood in the area.

Also, $20 \%$ of the respondents said they do receive relief materials from non-governmental organizatios (NGO's), 77.06\% opposed the claim regarding receiving assistance in the form of relief materials from NGO's, while the rest $2.94 \%$ were indifferent to the question.

Summary of the data on prevention measures adopted by respondents showed that $30.59 \%$ of the respondents resorted to contour or terrace farming to help mitigate the effect of flood on their farmlands and crops, $17.06 \%$ adopted cover cropping as a flood prevention measure, 37.65 engaged in opening of farm channels, 13.53\% resoted to construction farm dams while the rest $1.18 \%$ had no response to the question.

\subsection{Perception Of Respondents on the Effect of Flood on Farmlands Fertility in Relation to Crop Yield} Table 3: shows the responses given by the respondents on their perception of flood effect on farmlands fertility using crop yield as a factor.

Table 3: Respondents Perception of Flood Effects on Farmland Fertility

\begin{tabular}{lll}
\hline Effect of Flood on Farmlands Fertility & Respondents & Percentage (\%) \\
\hline Low Yield & 120 & 70.59 \\
Moderate Yield & 40 & 23.53 \\
High Yield & 10 & 5.88 \\
Total & $\mathbf{1 7 0}$ & $\mathbf{1 0 0}$ \\
\hline
\end{tabular}

Source: Field Work (2015)

Table 3 revealed that quite a large number of the respondents $(70.59 \%)$ believed that flood has negative effect on the fertility of farmlands thus, they said that flood occurrences will invariably result in low yield of crops from affected farmlands. Also, the next sets of the respondents representing about $23 \%$ responded to moderate yield while the rest and also the fewest set (5.88\%) responded to high crop yield. Collectively, a significant number of the respondents, responded to the low and high yield option and this implies that flood actually has more of adverse effects on farmlands fertility thereby reducing crop yields in the study area.

\subsection{RESEARCH HYPOTHESIS}

HO: Flood has no any significant effect on crops yield.

5.1 Hypothesis Testing

In other to draw valid conclusion in the investigation of flood effect on agricultural lands, the Pearsons Moment Correlation was used to correlate flood events and crop yields from $2006-2015$. The correlated result showed negative, which indicates negative effect on food production.

Table 4: Pearsons Product Moment Correlation Result

\begin{tabular}{|l|r|r|r|r|r|r|}
\hline Correlations & & & & & & \\
\hline & Years of Flood & \multicolumn{1}{|c|}{ Rice } & \multicolumn{1}{c|}{ Maize } & \multicolumn{1}{c|}{ Millet } & Guinea Corn & Groundnut \\
\hline Pearson Correlation & 1 & -.231 & -.400 & -.065 & -.043 & -.161 \\
\hline Sig. (2-tailed) & & .521 & .253 & .859 & .907 & .656 \\
\hline $\mathrm{N}$ & \multicolumn{1}{|l|}{10} & 10 & 10 & 10 & 10 & 10 \\
\hline **. Correlation is significant at the 0.01 level (2-tailed). \\
*. Correlation is significant at the 0.05 level (2-tailed). \\
\hline
\end{tabular}

The result of the correlation revealed that there is significant influence of flood on crops yields for Rice, Millet, Guinea corn, and Groundnut as indicated in the values respectively. The correlation is significant at 0.01 and 0.05 level.

\subsection{Flood Occurrence and Farmland areas Affected in the Study Area}

Figure 4.3 shows the variations in farmland areas affected by flood events in the study area over the period of ten years $(2006-2015)$. It revealed that there has been an increasing loss of farmland due to flood in the study area. Additionaly, the figure revealed that the years that more farmlands were lost in the years that recoreded severe flooding in the area than the other years. 


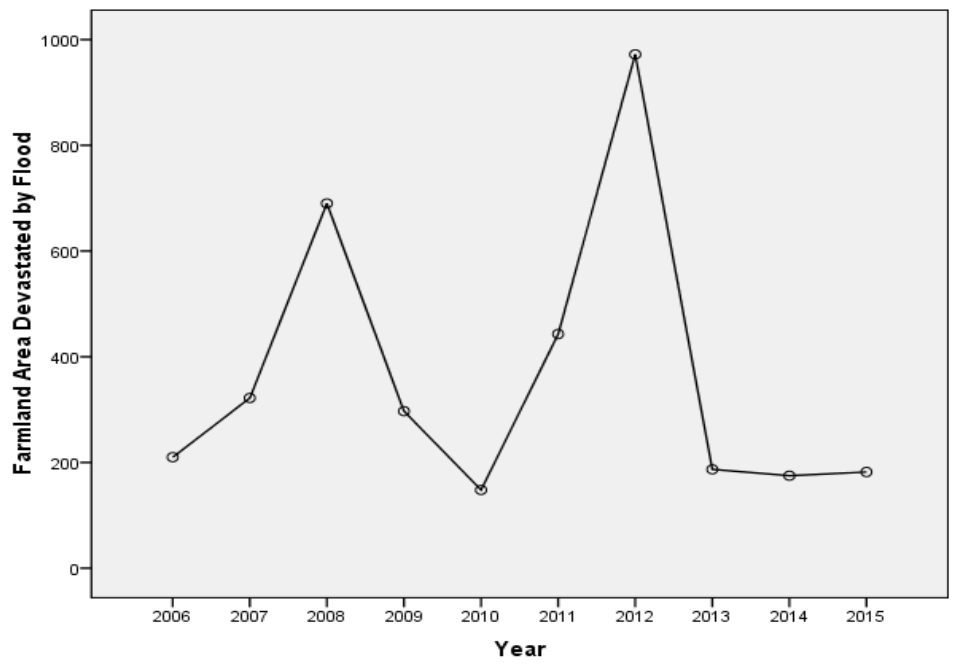

Fig. 5: Flood Occurrences and the Farmland Area Affected in the Study Area Source: Fieldwork (2015)

\subsection{FLOOD TREND IN THE STUDY AREA}

Figure 5 revealed an increase in rainfall giving rise to flood trend over the investigated years $(2006-2015)$. This is evident in the increased hectares of farmlands destroyed by flood and the low crop yield recorded in the sturdy area. The rainfall trend of the study area was prepared using the rainfall data of the study area which were obtained from NIMET (tables 4.7 - 4.7.9 in appendix). The figure shows that 2007, 2008, 2009, 2011, and 2012 are probably flood years in Doma. This is becouse total annual rainfall within these years are above the mean for the study period. This result is in concordance with the findings from field work which revealed the identified years as those during which the farms of most of the respondents were severely affected by flood.

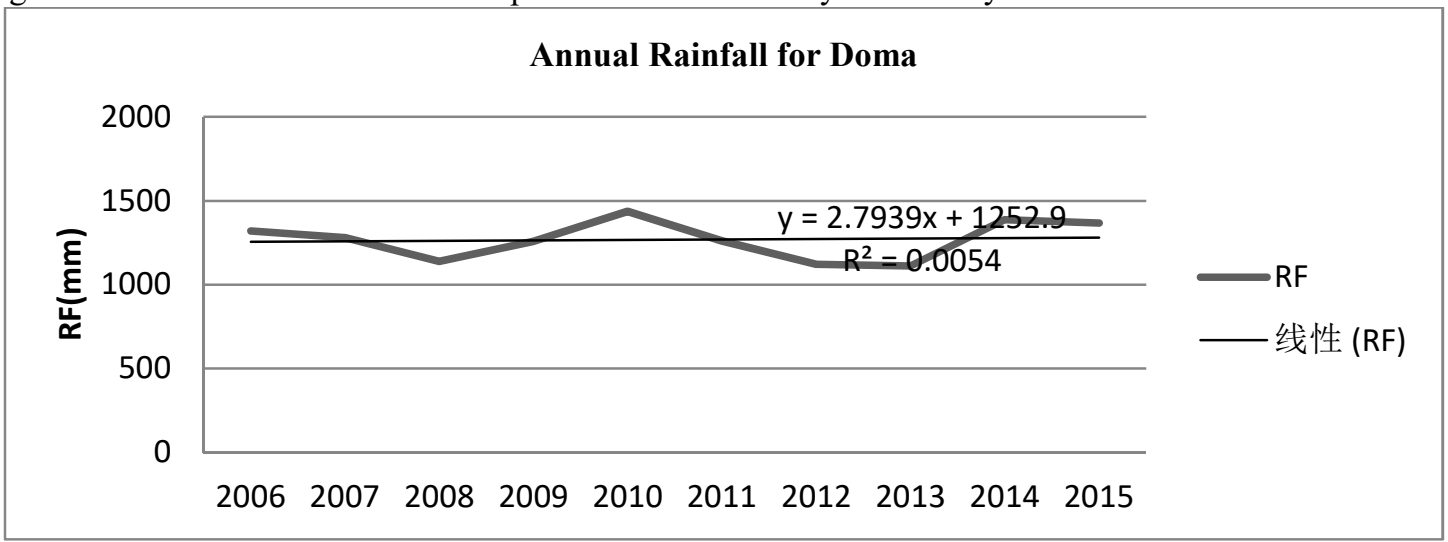

Source: Analysis of NIMET Raindfall Data (2015)

\section{Descriptive Statistics}

\begin{tabular}{|l|l|l|l|l|l|}
\hline & N & Minimum & Maximum & Mean & Std. Deviation \\
\hline Rainfall & 10 & 1112 & 1438 & 1268.30 & 114.960 \\
Valid N (listwise) & 10 & & & & \\
& & & & & \\
\hline
\end{tabular}




\section{Correlations}

\begin{tabular}{|ll|l|l|}
\hline & & Years & Rainfall \\
\hline Years & Pearson Correlation & 1 & .074 \\
& Sig. (2-tailed) & & .840 \\
& $\mathrm{~N}$ & 10 & 10 \\
\hline Rainfall & Pearson Correlation & .074 & 1 \\
& Sig. (2-tailed) & .840 & \\
& $\mathrm{~N}$ & 10 & 10 \\
\hline
\end{tabular}

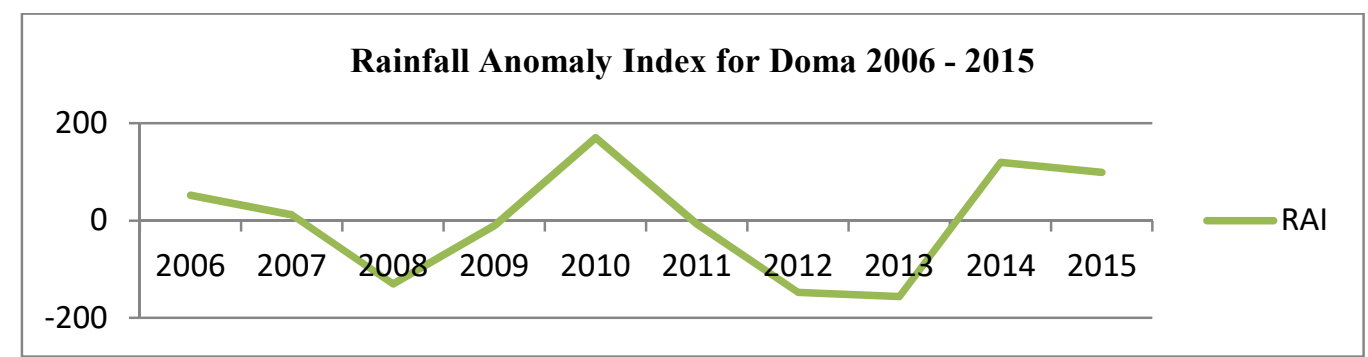

Source: Analysis of NIMET Rainfall Data (2015)

\subsection{CONCLUSION}

This has shown that flood events in Rukubi, Alage, SarkinDawaki, SabonGari, Doka and Agbashi communities of Doma Local Government area has damaged quite a significant hectares of farmlands and this has invariably resulted in infertility of the affected farmlands and reduction in crop yields. A large area of farmlands totalling 3,626 hectares has been rendered agriculturally unproductive or now possesses less productive ability due to the effect of flood in the areas. The main crops affected includes the core cereal and leguminous crops that are produced in the area which are Rice, Millet, Maize, Groundnut, and Guinea corn. In addition, the magnitude and the frequency of farmlands and crops affected by flood in the area is a function of their locations close to streams and rivers; and the high intensity of rainfall in the area. Also, it has been established that there is serious food shortage in the area following each flood occurrence due to several farmers' negligence to "NIMET" Seasonal Rainfall Prediction.

The effects of flood in the study area have been on the increase despite efforts taken by the respondents to prevent, reduce and control flood occurrences.

Giving the findings of the study on adaptation measures, it was also concluded that the state and the Local Governments, including the NGO's have done little to provide succor to the flood victims in the area.

\section{REFERENCES}

1. Abumere, S.I (1978): Agricultural Production in Nigeria.

2. Abumere, S.I (2001): Ecological Zones and Ecological Farm problems in Planning the Agricultural Sector in Nigeria.

3. Adefolalu, D.O. (2000) Nigeria: Effects of Climate Change in 1999. Minna: National Centre for Climate Change, FUT, Minna.

4. Aderogba, K.A. (2012). 'Global Warming and Challenges of Floods in Lagos Metropolis, Nigeria: Svap International, Ogun, Nigeria.

5. Ahmed, M.M. and Sanders, J.H. (1998). “Shifting from Extensive to Intensive Agricultural Systems: A Case Study in the Sudan.Agricultural Systems.

6. Akintola, F.O. (1974) "The Parameters of Infiltration Equations in urban LanduseSurfaces". Unpublished Ph. D Thesis, Department of Geography, University of Ibadan, Nigeria.

7. Akinyede, J.O. et al. (2012). 'Hydrologic Modelling of Katsina-Ala River Basin : An Emerging Scenario from Lake Nyos Threat: African Regional Centre for space Science and Technology Education in English (ARCSSTE-E) Ile-Ife, Nigeria.

8. Albert, Robert W. American Civil Engineering Practice, John Wiley and Sons, 1956.

9. Bachana, K. and Pugh, B. (1995): Introduction to Soil Study Widen Field and Nicolson, London.

10. Barlowe, R. (1978). Land Economics: Economics of Real Estate. Prentice-Hall Inc. Engle Cliffs, New Jersey.

11. Bunting, B.T. (1996): The geography of Soil. Hutchinson, London.

12. Bunting, L.R (2012): World on the Edge. Earth Policy Institute: Norton. 
13. Burton, I.K. et al (1978). 'Environmental Hazard' Oxford University Press, London.

14. Chapman, T. (2002). 'Major Flooding and Increased Flood Frequency in Scotland Since 1988' Wiley, New York.

15. Chorly, R.J. 91978). 'Introduction to Geographical Hydrology' Methuen and Company Ltd.: New York.

16. Chow, V.T. (1948). Aplied Hydrology-Civil Engineering.Mcgraw Hill Higher Education.

17. Chow, V.T. (1964) Handbook of Applied Hydrology. New York: Mcgraw-Hill.

18. Christopherson, R.W. (1997). 'Goesystems: An Introduction o Physical Geography'. London: Prentice-Hall (Third Edition).

19. Das, D.K. (1997). 'The New Paradigm of Soil Resilience and Sustainability in Crop Production'. Presidential Delivered at $62^{\text {nd }}$ AGM Indian. Soc. Soil Science.Held at Science City Calcutta.Vol. 45.

20. Deckshatuhi, B.C and George, J. (1993). 'Science of Remote Sensing for National Development'.Volume 61, No 3 and 4 Indian Science Academy.

21. DHA (1994) Disasters Around the World-A Global and regional. Information Pap. No. 4 World Conference on Natural Disaster Reduction, Yokohama, May, 1994.

22. Directive 2007/60/EC chapter 1 Article 2 eur-tex-europa.ev.Retrieved on 2012.

23. Durotoye, B. (1999). Human Occupation of Hazard Area in Nigeria', in: Oshuntokun, A. (ed) Environmental Problems of Nigeria. Lagos: Friedrich Ebert Foundation.

24. Etuonovbe, A.K. (2011). 'The Devastating Effect of Flooding in Nigeria Marrakech, Morocco.

25. Food and Agricultural Organization (1977): Assessing Soil Degradation FAO Soil Bulletin No. 34 Rome

26. Food and Agricultural Organization (2005).

27. Food and Agricultural Organization (2005): World Agriculture Towards 2015/2030.

28. Geraghty, J.J. et al (1973) Water Atlas of the United State. New York: Water Information Centre.

29. Glossary of Meteorology, 2000.

30. Gumbel, E.J. (1941). The Return Period of Flood Flows. Annals of Mathematical Statistic, 12 92) pp. 163190 .

31. Herrngton, J. (1989). 'Planning Process: An Introduction for Geographers'.

32. Hewitt, K. and Bruton, I. (1971). The Hazardousiness of a Place: A Regional Ecology of Damaging Events. London.

33. http://www.feo.org.food and Agricultural organization Bulletins.

34. Johnson, T. (2001). 'Northern Nigeria hit by Floods' Newsletter October 5, 2001.

35. Landbein, W. B. (1979) Flood in Encyclopardia Americana, Vol. 11 Pp. 408-414.

36. Leopold, L.L.B. and Maddock. T. Jr., (1954) Hydrulic Geometry of Stream Channels and Some Physiographic Implications. USGS Prof..paprer 252,p.57.

37. MSN Encarta Dictionary.Flood.Retrieved on 2006-12-28. Archived 2009-10-31

38. New York State Climate Office (2009). Climate Change Newsletter June, 2009.

39. Nicholas, F. and Foskett, R. (1999).Conservation.Popular Science Series Hodder and Slouglition, London.

40. Okoji, G. et al (2012). 'Flood Analysis' Leadership Newspaper, Sunday 19.

41. Omuta, (1988) Flood Problem in Benin City. In: Environmental Issues and Management in Nigeria Development (Eds) Sada, P.O and Odemerho, O.F. Ibandan: Evens.

42. Oyo States Government (1981): Oyo State Diary of Events.

43. Prelty, J.N. (1995). Regenerating Agriculture: Policies and Practice for Sustainability and Self-Reliance. London, Earthscan, Practical Strategy.

44. Rostvedt, J.O. (1968) 'Summary of Floods in the United States during 1963' U.S Department of the Interior.Geological Survey.

45. Smith, B. (2001). Adaptation for Climate Change in the Context of Sustainable Development, in Climate Chanfge 2001: Impacts Adeptation and Unreality' Contribution of Working Group 11 to the Third Assessment Report of IPCC, Cambridge, University Press.

46. Smith, J.B. Klein, R.J.T. and Huq, S. (2003). "Climate Change, Adaptive Capacity and Development" Imperial College Press, London.

47. Smith, K. and Tobin. C.A. (1979) Human Adjustment to the Flood Hazard New York Longman

48. Taiwo, O. (2008). 'Flood Sacks 500 in Babura' in this day Vol. 13. No. 4867: P.18.

49. Thompson, B. (2000). Sustainable Agriculture Automated Database Searches AFSIC, U.S. National and Regional Groups in Research, Outreach, Advocacy and Production Expertise.

50. Thorne, D.W and Thorne M.D (1979) Soil, Water and crop Production p. 353.

51. Thurston, H. David (1990): Plant Disease Management Practices of Traditional Farmers.

52. Trotter, C.M. 91991). Remotely Sensed Data as an Information Source Geographical Information System in Natural Resources Management: A Review. International Journal of Geographical Information Systems, Vol. 2, 1991.

53. U.S. Water Resources Council (1981) “Guidelines for Determining Flood Flow Frequency” Bull. No. 17b.U.S 
Water Resources Council. Washington DC.

54. United Nations, (2003).Sustainable Devlopment Issues. Geneva: UN Division for Sustainable Development Issues.

55. United States Department of Interior, Bureau of Reclamation, Design of small dams, United States Government Printing Office, 1973.

56. Usman A.A (1991). A Comparative Analysis of Aerial Photographs, Landsats MSS and Spot for Providing Information for Agricultural Development. Msc Thesis, Land Resources Programme, Bayero University Kano.

57. Vaghani, V.A. (2008). Flood Impact Analysis Using GIS: A Case Study for Lake Roxen and Lake GlanSweden Masters Thesis, Linkopings University Sewden.

58. Van-Duivenbooden, N. (1995).Landuse Systems Analysis as a Tool for Land Use Planning with Special Reference to North and West African Agro-Ecosystems Phd Thesis Wageningen Agricultural University.

59. Walker, Sir G.T. (1923) Correlation in Seasonal Variations of Weather. Viii A Preliminary Study of World Weather.Mem India Met Dept.24, pp. 75-131.

60. Waltham. T. (1978). Catastrophe: The Violent Earth PP.80-103.

61. Ward R.C (1967) Principles of Hydrology London. Macmillan pp.324-326.

62. Ward R.C. (1967) Flood A Geographical Perspectives. New York John Wiley.

63. Ward, R. (1978). Floods, a Geographical Perspective London: Macmillan.

64. Warner. K. (1991).Shifting Cultivators: Local Technical Knowledge and Natural Resources Management in the Humid Tropics FTP. Community Forestry Note 8, FAO, Rome.

65. Warren, D.M. (1991). Using Indigenous Knowledge in Agricultural Development. The World Bank Washington DC.

66. Waylen. P. and Won, M-K (1982) Prediction of Annual Floods Generated by Mixed Process. Water resources research 18. 1283-1286.

67. Waymire. E. Gupra. V.K and Rodriguez-Iturbe. I. (1984) A Special Theory of Rainfall Intensity at the Meso(B) Scale. Water Resources research 20. 1453-1465.

68. Werner, MGF. Hunter, NM. Bates, PG (2006). "Identifiability of Distributed Floodplain

69. White, G.F (1964) Choice of Adjustments to Floods University of Chicago Department of geography: Research Paper No. 93: University of Chicago Press.

70. Wilson, A. and TrychiieWicz, A. (1995). Agriculture and Sustainable Development: Policy Analysis on the Great Plains Winnipeg: International Institute for Sustainable Development.

71. Wisler.C.O. and Brater, E.F. 1959) Hydrology. New York: John Wiley and Sons. Pp. 31-56.

72. WMO (World Meteorological Organization) (1975) Drought and Agriculture, WMO Technical Note No. 138.WHO-No.392, Secretariat of the World Meteorological Organization. Geneva, Switzerland.

73. Worldwide Web (www) Sites Visited.

74. Wright, E.G. (1978) Flood in Encyclopedia Americana, Vol, 11, pp. 414-415. 